\title{
Effect of a stabilizing additive on the electroconductivity of $\mathrm{ZrO}_{2}$-based ceramics
}

\author{
(C) Yulia A. Mityushova, ${ }^{1,2+}$ Alexey A. Markov, ${ }^{2}$ Elmira I. Denisova, ${ }^{3}$ \\ Vadim V. Kartashov, ${ }^{3}$ and Sergey A. Krasikov ${ }^{1}$ * \\ ${ }^{1}$ Laboratory of High Entropy Alloys. Institute of Metallurgy of the Ural Branch of the Russian Academy \\ of Sciences. Amundsen St.,101. Ekaterinburg,620016.Russia.E-mail:mityushova_yulia@mail.ru \\ ${ }^{2}$ Laboratory of Oxide Systems. Institute of Solid State Chemistry of the Ural Branch of Russian Academy \\ of Sciences. Pervomaiskaya St., 91. Ekaterinburg, 620990. Russia. \\ ${ }^{3}$ Department of the Rare-metals and Nanomaterials. FTI UrFU. Mira St., 19. Ekaterinburg, 620000. Russia.
}

Keywords: solid oxide fuel cell, ceramics, zirconium dioxide, stabilizing additive.

*Supervising author; ${ }^{+}$Corresponding author

\section{Abstract}

The creation of solid oxide fuel cells (SOFC) is one of the promising solutions to the problem of electricity supply. It is advantageous to use stabilized zirconium dioxide $\left(\mathrm{ZrO}_{2}\right)$ as solid electrolytes in SOFC.

In this paper, zirconium dioxide powders with additives of yttrium and scandium oxides $\left(\mathrm{ZrO}_{2}-\mathrm{Y}_{2} \mathrm{O}_{3}\right.$, $\mathrm{ZrO}_{2}-\mathrm{Sc}_{2} \mathrm{O}_{3}$ and $\mathrm{ZrO}_{2}-\mathrm{Y}_{2} \mathrm{O}_{3}-\mathrm{Sc}_{2} \mathrm{O}_{3}$ ) were synthesized. Ceramic samples were obtained from the powders to study the effect of stabilizing additives on the conductive properties of zirconium dioxide. The addition of yttrium oxide $\mathrm{Y}_{2} \mathrm{O}_{3}$ in an amount of 8 mol. \% contributed to the formation of a solid cubic solution of zirconium dioxide, and scandium oxide $\mathrm{Sc}_{2} \mathrm{O}_{3}$ increased the strength and conductive characteristics of the material. The definition of the conductive characteristics was carried out by impedance spectroscopy. Platinum paste was preliminarily applied by printing, which, when measured, ensured contact with the entire surface of the sample under study.

It is shown that the addition of yttrium oxide contributes to the formation of a solid cubic solution of zirconium dioxide, and scandium oxide increases the strength (microhardness) and conductive characteristics of the material. Of interest is the simultaneous alloying of zirconium dioxide with scandium and yttrium oxides. The results of determining the properties of ceramic samples showed that the increase in electrical conductivity is more influenced by the addition of $\mathrm{Sc}_{2} \mathrm{O}_{3}$ compared with the addition of $\mathrm{Y}_{2} \mathrm{O}_{3}$. Stabilization without yttrium oxide leads to unstable conductivity values over time. A sample of $\mathrm{ZrO}_{2}-1 \mathrm{~mol} \%$. $-\mathrm{Y}_{2} \mathrm{O}_{3}-$ $8 \%$ mol. $\mathrm{Sc}_{2} \mathrm{O}_{3}$ has the potential to be used as an electrolyte in solid oxide fuel cells.

\section{References}

[1] V.N. Chebotin, M.V. Perfiliev. Electrochemistry of solid electrolytes. Moscow: Chemistry. 1978. 312p. (russian)

[2] E.M. Zhilina, S.N. Agafonov, A.S. Russkih, S.V. Zhidovinova, V.P. Chentsov, and S.A. Krasikov. Aluminium interaction with multicomponent oxide system consisting of zirconium, titanium, silicon, iron. Butlerov Communications. 2017. Vol.51. No.7. P.55-60. DOI: 10.37952/ROI-jbc-01/17-51-7-55

[3] E.M. Zhilina, S.A. Krasikov, S.N. Agafonov, L.B. Vedmid, and S.V. Zhidovinova. Thermodynamic and kinetic peculiarities of joint aluminothermic reduction of titanium and zirconium from oxides. Butlerov Communications. 2016. Vol.45. No.1. P.130-135. DOI: 10.37952/ROI-jbc-01/16-45-1-130

[4] Yu.S. Rutman, S.Yu. Toropov, Pliner, et al. High-refractory materials from zirconium dioxide. Moscow: Metallurgy. 1985. 137p. (russian)

[5] V.V. Kartashov, É.I. Denisova, A.V. Vlasov, D.K. Aleshin, A.A. Blinnichev. High-strength ceramic based on zirconium dioxide: Preparation and properties. Refractories and Industrial Ceramics. 2010. Vol.51. Iss.2. P.104-106.

[6] N.V. Obabkov, A.V. Shak, Yu.D. Afonin. General materials science. Laboratory workshop. Publishing house of the UrFU, Ekaterinburg. 2015. 97p. (russian)

[7] M. Perfiliev, A. Demin, B.B. Kuzin, A.S. Lipilin. High-temperature electrolysis of gases: Scientific publication. Ed. ed. S.V. Karpachev; Academy of Sciences of the USSR. Ural detachment Institute of Electrochemistry. Moscow: Science. 1988. 230p. (russian)

[8] V.N. Chebotin, M.V. Perfilev. Electrochemistry of solid electrolytes. Moscow: Chemistry. 1978. (russian) 
[9] V.V. Ivanov, S.N. Shkerin, A.S. Lipilin, A.V. Nikonov, V.R. Khrustov, Al.A. Rempel. The electrical conductivity of a solid electrolyte based on zirconium dioxide with a ceramic grain size in the submicron range. Electrochemical energy. 2010. Vol.10. No.1. P.3-10. (russian)

[10] E.E. Lomonova. Technology, properties and application of crystals based on zirconium dioxide: dis. Cand. tech. sciences. Moscow. 2001. 349p. (russian)

[11] S.S. Batsanov. Structural chemistry. Facts and dependencies. Moscow: Dialogue-MSU. 2000. 291 p. http://www.chem.msu.su/rus/elibrary/bazanov/glava2(3).pdf (russian) 